\title{
PENGUSAHAAN DAN KELEMBAGAAN LAHAN PERTANIAN DI BERBAGAI AGROEKOSISTEM (KASUS DESA-DESA PATANAS)
}

\author{
Supadi \\ Pusat Analisis Sosial Ekonomi dan Kebijakan Pertanian Bogor
}

\begin{abstract}
In trying to get his land the farmer must consider the technical problem, economical and social the culture, the exploitation of agriculture always was linked with what will be produced, how many, here, when, how and where is distributed him. The utilization of the farmer's land as the production factor that was most important in the farming really was influenced by the relations kind between humankind and his land because will be related to in continuation of his farming. The land that was made an effort to get could take the form of his property personally or property of the other person. This research was aimed at identifying and analyzing the exploitation and institutional the agricultural land in rural areas. The method used was survey that was carried out in 12 Patanas villages that were spread in Lampung, West Java, Central Java, East Java, South Sulawesi, and NTB. In three villages, 25 farm households were selected. Results of the research showed the growth index reached 200 to 300, except in the paddy-field land where its irrigation was rotated and in dryland that was cultivated with cassava. The farmer used the superior variety seed, but did not yet apply balanced fertilizing. Fertilizing exceeded the recomendation whereas for other fertilizer $\left(\mathrm{PO}_{5}\right.$ and $\left.\mathrm{K}_{2} \mathrm{O}\right)$ and relative manure utilization was still under recommendation, in fact some farmers did not use. The productivity of the crop in the rainy season (rice and corn) higher was compared to dry season, except for the potato. Generally the farmer used capital personally, "YARNEN" system was an alternative that often was followed. The price of agricultural product was fluctuating in which the price of the dry season tended to be higher than in the rainy season, the status of the farmer was dominated by owner followed by the sharecropper and the leaser. The sharecropper and the leaser always did not come from the group landless because of the owner, also entered the rented market and sharecropper. The rented system that more stressed the aspect of economics than social more prominent in production centers of the potato.
\end{abstract}

Keyword: farming, institutional the land, agroecosystem

\section{PENDAHULUAN}

Lahan di daerah pedesaan merupakan faktor dominan baik sebagai lahan pertanian maupun sebagai tempat tinggal. Di dalam unit ekonomi lahan merupakan sumber utama pendapatan, dalam unit sosial lahan menggambarkan status sosial dan dalam unit keluarga lahan merupakan harta warisan yang paling berharga. Oleh karena itu pertumbuhan penduduk tanpa diikuti dengan pertambahan lahan yang memadai akan mengakibatkan kesenjangan dalam unitunit tersebut di desa yang bersangkutan, karena ketidaksamaan kekuatan para pelaku dan mengakibatkan ketidak merataan dalam pembagian hasil. 
Di pedesaan berusaha pada usahatani merupakan sumber pendapatan yang masih dominan. Artinya pendapatan yang berasal dari usahatani memiliki peranan yang besar terhadap kontribusi pendapatan rumah tangga.

Berusahatani adalah mengusahakan dan memanfaatkan sumberdaya lahan secara langsung yang dilakukan petani berkenaan dengan lahan yang menjadi haknya (menggarap lahan milik sendiri ataupun milik orang lain baik melalui sakap, sewa atau gadai). Pengusahaan lahan pertanian dalam arti menggarap lahan untuk memperoleh hasil atau pendapatan tersebut menghendaki petani untuk melaksanakan budidaya (Ilahauw et al dalam Mubyarto 1985). Menurut Hermanto (1984) kemampuan petani dalam mengusahakan lahan pertaniannya dipengaruhi unsur modal, tenaga kerja dan manajemen.

Dalam setiap program pertanian hasil yang akan dicapai selalu ada kaitannya dengan struktur dan penggunaan lahan (land tenure) karena aspek ini implikasinya sangat luas bagi keberhasilan program-program pertanian (Mubyarto 1983).

Pengusahaan lahan pertanian selalu berkaitan dengan apa yang akan diproduksi, berapa banyak, dengan cara atau metode apa, dimana, kapan, dan bagaimana mendistribusikannya. Sebagian besar bersifat landbased, sehingga proses produksi pertanian sangat dipengaruhi oleh karakteristik agroekosistem dimana unsur-unsur utamanya adalah lahan, air, iklim (suhu, curah hujan, kelembaban, sinar matahari), biota setempat, struktur penguasaan dan kelembagaan lahan (Sumaryanto dan Pasaribu 1996). Menurut BPS sumberdaya lahan pertanian terbagi dalam dua kelompok besar yaitu 1) lahan sawah dan 2) lahan kering. Lahan sawah dapat dibagi menjadi lahan sawah irigasi dan non irigasi, sedangkan lahan kering dapat berupa tegalan/ladang, kebun dan hutan rakyat.

Berusahatani merupakan upaya untuk meningkatkan produksi baik untuk tujuan konsumsi maupun tujuan meningkatkan pendapatan petani. Banyak faktor yang mempengaruhi keputusan petani dalam usahatani yang dilaksanakan. Menurut Shanner (1982) faktor-faktor tersebut meliputi lingkungan fisik (tanah dan agroklimat), biologi, kondisi pengairan, ketersediaan teknologi, sistem penunjang (modal/kredit, pasar input, pasar output, penyuluh dan sumberdaya petani). Pada kenyataannya petani selalu dihadapkan pada berbagai keterbatasan dalam memilih usahatani komoditas yang akan diusahakan, alokasi biaya dan pencapaian keuntungan yang tinggi.

Permasalahan yang dihadapi petani dalam mengusahakan lahan pertaniannya sangat kompleks meliputi aspek penerapan teknologi budidaya, status dan luas lahan yang diusahakan, aksesabilitas secara fisik dan ekonomi terhadap sarana produksi (termasuk permodalan dan 
pemasaran hasil) dan tingkat efisiensi usahatani. Dalam pengusahaan lahan pertanian yang menjadi persoalan adalah belum mencapai tahap yang dapat mencapai keseimbangan, karena kenaikan harga output usahatani yang diterima petani tidak sebanding dengan kenaikan harga input produksi yang harus dibayar petani, bersamaan dengan itu juga disertai dengan semakin lambatnya peningkatan produktivitas usahatani secara keseluruhan (Nurmanaf et al 2004 dan Sugiarto 1996).

Di tengah perubahan struktur ekonomi seperti sekarang, permasalahan pengusahaan lahan (termasuk di dalamnya penguasaan dan kelembagaan lahan) di pedesaan masih penting karena beberapa hal antara lain: a) banyak bukti empiris yang menunjukkan bahwa efektivitas program peningkatan produksi pertanian, peningkatan pendapatan petani ataupun pemerataan hasil-hasil pembangunan seringkali menghadapi kendala penguasaan (status dan luas) lahan di pedesaan yang tidak kondusif untuk menunjang program tersebut, b) di tengah arus modernisasi dan urbanisasi spektrum permasalahan yang berkaitan dengan fungsi lahan semakin luas dan kompleks. Lahan bukan lagi sekedar faktor produksi tetapi telah berkembang sebagai komoditas, sehingga konflik-konflik sosial yang terjadi semakin sering dan rumit, c) lahan dibutuhkan oleh hampir semua aktivitas ekonomi, sehingga kelangkaannya meningkat dengan pesat. Di antara berbagai jenis sumberdaya, lahan merupakan sumberdaya alam yang sangat strategis sehingga dinamika permasalahan sosial ekonomi banyak terkait dengannya.

Penerapan teknologi dalam proses produksi merupakan upaya untuk memperoleh hasil ekonomi yang optimal. Semakin tinggi penerapan teknologi semakin besar pula tuntutan penyediaan modal dan tenaga kerja yang cukup. Namun pada umumnya petani mengalami kekurangan modal karena hanya mengandalkan modal sendiri sehingga terkadang dijumpai kurang terdapat perbedaan yang nyata dalam penerapan teknologi antar usahatani. Dalam hal ini baik antar usahatani dengan luas yang berbeda maupun dengan perbedaan status pengusaan lahannya (llahauw dalam Mubyarto 1985). Menurut Husodo (2003) penggunaan teknologi intensif yang sarat dengan input (pupuk dan pestisida) jarang diadopsi secara sempurna oleh petani mengingat nilai pengembalian hasil (yield return value) tidak memberikan insentif progresif. Ragam kualitas sumberdaya petani yang tinggi terhadap kemampuan iptek menyebabkan alih teknologi tidak berjalan lancar sehingga ragam kualitas produk menjadi tinggi dan hal ini menyulitkan pemasaran produk tersebut. Dewasa ini disamping konversi lahan juga fragmentasi lahan seakan tidak dapat dibendung, sehingga petani semakin terperangkap di jurang kemiskinan (poverty trap). 
Pada dasarnya dalam proses pembangunan ekonomi nasional potensi ekonomi pedesaan yang bersifat land based akan menjadi determinan perekonomian secara keseluruhan. Pola pengusahaan lahan seringkali dapat dijadikan gambaran pemerataan faktor produksi sebagai sumber pendapatan dan sebagai indikator tingkat kesejahteraan, meskipun tidak dapat sepenuhnya mencerminkan keadaan sebenarnya tingkat kesejahteraan itu (Susilowati 1996).

Tulisan ini bertujuan mengidentifikasi dan menganalisis pengusahaan komoditas dan kelembagaan lahan pertanian di berbagai agroekosistem. Indikator yang mendapat penekanan adalah indeks pertanaman, penerapan teknologi, penggunaan tenaga kerja, penyebaran lahan usahatani, produktivitas usahatani, permodalan, pemasaran hasil dan kelembagan penguasaan lahan. Hasil penelitian yang berupa data dan informasi diharapkan dapat memberi manfaat bagi pihak yang berkepentingan.

\section{METODOLOGI PENELITIAN}

\section{Lokasi Penelitian dan Responden}

Lokasi penelitian meliputi enam provinsi, yaitu Lampung, Jawa Barat, Jawa Tengah, Jawa Timur, Sulawesi Selatan dan Nusa Tenggara Barat. Di setiap provinsi secara sengaja dipilih dua desa sampel (desa Patanas), sehingga terdapat dua belas desa sampel (Tabel 1). Komoditas yang dipilih adalah, padi, jagung, ubi kayu, kentang, bawang putih dan tembakau. Di setiap desa diwawancarai 25 rumah tangga responden yang seluruhnya merupakan petani.

Tabel 1. Desa-desa Penelitian Menurut Basis Agroekosistem dan Komoditas Dominan, Patanas, 2005

\begin{tabular}{|c|c|c|c|c|c|}
\hline No & Provinsi & Kabupaten & Desa & $\begin{array}{l}\text { Agroeko- } \\
\text { sistem }\end{array}$ & $\begin{array}{l}\text { Komodita } \\
\text { s Dominan }\end{array}$ \\
\hline 1. & Lampung & $\begin{array}{l}\text { Lampung } \\
\text { Tengah } \\
\text { Lampung } \\
\text { Tengah }\end{array}$ & $\begin{array}{l}\text { Komering } \\
\text { Putih } \\
\text { Sumberrejo }\end{array}$ & $\begin{array}{l}\text { Lahan } \\
\text { kering } \\
\text { Lahan } \\
\text { sawah } \\
\text { Lahan }\end{array}$ & $\begin{array}{l}\text { Ubi kayu } \\
\text { Padi }\end{array}$ \\
\hline 2. & Jawa Barat & $\begin{array}{l}\text { Karawang } \\
\text { Bandung }\end{array}$ & $\begin{array}{l}\text { Sampalan } \\
\text { Sukaluyu }\end{array}$ & $\begin{array}{l}\text { sawah } \\
\text { Lahan } \\
\text { kering }\end{array}$ & $\begin{array}{l}\text { Padi } \\
\text { Kentang }\end{array}$ \\
\hline 3. & Jawa Tengah & $\begin{array}{l}\text { Banjarnegara } \\
\text { Pati }\end{array}$ & $\begin{array}{l}\text { Karang } \\
\text { Tengah } \\
\text { Mojoagung }\end{array}$ & $\begin{array}{l}\text { Lahan } \\
\text { kering } \\
\text { Lahan } \\
\text { kering }\end{array}$ & $\begin{array}{l}\text { Kentang } \\
\text { Ubu kayu }\end{array}$ \\
\hline 4. & Jawa Timur & $\begin{array}{l}\text { Jember } \\
\text { Kediri }\end{array}$ & $\begin{array}{l}\text { Sumber } \\
\text { Kalong } \\
\text { Selosari }\end{array}$ & $\begin{array}{l}\text { Lahan } \\
\text { sawah } \\
\text { Lahan } \\
\text { sawah }\end{array}$ & $\begin{array}{l}\text { Tembakau } \\
\text { Padi }\end{array}$ \\
\hline
\end{tabular}




\begin{tabular}{lllcl} 
5. Sulawesi & $\begin{array}{l}\text { Sidrap } \\
\text { Selatan }\end{array}$ & $\begin{array}{l}\text { Lahan } \\
\text { Jeneponto }\end{array}$ & $\begin{array}{l}\text { Pawah } \\
\text { Rumbia } \\
\text { Lahan } \\
\text { kering } \\
\text { Lahan }\end{array}$ & $\begin{array}{l}\text { Padi } \\
\text { Jagung }\end{array}$ \\
6. NTB & $\begin{array}{l}\text { Lombok Timur } \\
\text { Lombok } \\
\text { Tengah }\end{array}$ & $\begin{array}{l}\text { Karang Baru } \\
\text { Sanjak }\end{array}$ & $\begin{array}{c}\text { Bawang } \\
\text { Lahan } \\
\text { sawah }\end{array}$ & $\begin{array}{c}\text { puth } \\
\text { Padi }\end{array}$ \\
\hline
\end{tabular}

\section{Jenis dan Analisis Data}

Data yang digunakan terutama data primer. Data primer dikumpulkan melalui wawancara dengan masing-masing responden secara individual dengan menggunakan kuesioner terstruktur. Selain data primer juga dikumpulkan melalui wawancara kelompok (group interview) yang melibatkan tokoh kunci di desa seperti, Kepala Desa atau Pamong Desa, Petugas Pertanian, Ketua Kelompok Tani dan Tokoh Masyarakat lainnya dengan menggunakan kuesioner semi terstruktur.

Secara umum analisis deskriptif merupakan alat utama dalam penelitian ini dengan menggunakan metode hitungan seperti persentase, frekuensi rata-rata, distribusi dan lain-lain dan selanjutnya disajikan dalam bentuk tabulasi tunggal dan silang terhadap persoalan yang dianalisis.

\section{HASIL DAN PEMBAHASAN}

\section{Pengusahaan dan Kelembagaan Lahan}

\section{Pengusahaan Lahan Pertanian}

Di antara berbagai jenis sumberdaya, lahan merupakan sumberdaya alam yang strategis. Faktor produksi lahan mempunyai kedudukan penting dalam budidaya pertanian yang ditunjukkan dari besarnya jasa yang diberikannya dibandingkan faktor-faktor produksi lain (Mubyarto 1983). Disamping sebagai faktor produksi terpenting, pemilikan lahan dapat menentukan status sosial pemiliknya.

Di dalam pengusahaan lahan pertanian, para petani dituntut untuk mengambil keputusan atau pilihan dari beberapa alternatif yang ada. Keputusan yang harus diambil antara lain mencakup penentuan jenis tanaman/pola tanam, waktu tanam, penerapan teknologi (penggunaan benih/bibit, pemupukan, penggunaan insektisida atau alat pertanian yang digunakan). Petani sebagai pengelola harus dapat pula menentukan jumlah tenaga kerja dan dapat mengatur penggunaan hasil produksi untuk dijual ke pasar dan untuk konsumsi. Pengusahaan lahan pertanian memerlukan modal untuk kelangsungan proses produksi yang berkelanjutan. Modal 
merupakan faktor yang sangat penting setelah lahan. Pengusahaan lahan akan lebih efisien bila lahan yang diusahakan berada dalam satu kesatuan areal yang utuh.

\section{Pola Pertanaman}

\section{a. Pola Pertanaman di Desa Agroekosistem Sawah}

Untuk desa sawah, padi merupakan komoditas utama. Namun untuk desa-desa tertentu, seperti Karangbaru dan Sumberkalong meskipun berbasis sawah, untuk penanaman musim kemarau (MK I atau MK II) terdapat perbedaan, di Karangbaru, ditanami bawang putih dan di Sumberkalong tembakau. Di Sumberkalong, pada musim hujan selain ditanami padi juga banyak yang menanam jagung.

Pola tanam padi-padi-bera sangat menonjol di Sampalan, Sumberejo dan Passeno. Sedangkan di Gonjak dan Selosari masing-masing padi-padi-palawija/tembakau dan padi-padipalawija/hortikultura. Sedangkan di Karangbaru lebih beragam padi-padi-palawija/ hortikultura/ tembakau atau padi-bawang merah/ bawang putih-palawija/hortikultura. Khusus di Sumberejo sudah sejak lama diberlakukan pergiliran pengairan setiap tahunnya, sehingga pada musim kemarau pada tahun tertentu tidak mendapat giliran pengairan, misalnya pada MK I tahun 2004 tidak dapat dilaksanakan pertanaman padi dan diganti oleh jagung. Malahan banyak petani yang memberakan lahannya (70 persen).

\section{b. Pola Pertanaman di Desa Agroekosistem Lahan Kering}

Di desa lahan kering pola tanam umumnya bervariasi tergantung komoditas yang diusahakan (Tabel 3). Komoditas utama untuk lahan kering adalah kentang, diusahakan di Sukaluyu dan Karangtengah, ubikayu di Komeringputih, ubikayu di Mojoagung dan jagung di Rumbia.

Tabel 3. Pola Tanam di Desa Beragroekosistem Lahan Sawah dan Lahan Kering, Patanas, 2005.

\begin{tabular}{|c|c|c|}
\hline & $\begin{array}{l}\text { Agroekosistem/ } \\
\text { Desa }\end{array}$ & Pola Tanam \\
\hline I. & Lahan sawah & \\
\hline 1. & Sumberejo & padi-padi-bera/padi-jagung-bera \\
\hline 2. & Sampalan & padi-padi-bera \\
\hline 3. & Selosari & padi-padi-palawija/hortikultura \\
\hline 4. & Gonjak & padi-padi-palawija/tembakau \\
\hline 5. & Passeno & padi-padi-bera \\
\hline 6. & Karangbaru*) & $\begin{array}{l}\text { padi-padi-palawija/hortikultura/tembakau } \\
\text { padi-bawang merah/putih-palawija/hortikultura }\end{array}$ \\
\hline 7. & Sumberkalong ${ }^{* *}$ ) & padi/jagung-tembakau-cabai \\
\hline I. & Lahan kering & \\
\hline 1. & Komering Putih & Ubikayu \\
\hline
\end{tabular}



2. Mojoagung
Ubikayu
3. Sukaluyu
kentang-kubis-petsai/jagung; kubis-kentang-petsai;
4. Karangtengah
kentang-kentang/jagung; kentang-wortel/cabai
5. Rumbia
kentang-kentang-kentang
jagung-jagung-bera

Keterangan :

${ }^{*}$ ) sentra produksi bawang putih

${ }^{* *}$ ) sentra produksi tembakau

Penanaman kentang di Karangtengah dilakukan tiga kali dalam setahun, sedangkan di Sukaluyu pada umumnya dilakukan satu kali setahun, paling banyak dua kali dalam setahun. Pola tanam setahun di Sukaluyu beragam. Setelah menanam kentang (di Sukaluyu) dapat dilanjutkan dengan menanam kubis, petsai, wortel, jagung atau kentang sekali lagi.

Di Komering Putih dan Mojoagung pola tanam dominan adalah ubikayu sepanjang tahun. Mojoagung selain sebagai sentra ubikayu juga merupakan daerah tebu. Di Rumbia penanaman jagung dilakukan dua kali setahun.

Dengan melihat pola pertanaman di kedua agroekosistem tersebut maka IP-nya pada umumnya telah mencapai 200 bahkan 300, kecuali untuk sentra produksi ubikayu yang hanya ditanami sekali dalam setahun dan padi di Sumberejo terutama bila penanaman musim kemaraunya tidak mendapat giliran pengairan.

\section{Penerapan Teknologi}

\section{a. Varietas}

Varietas padi yang ditanam di desa sawah pada umumnya varietas Ciherang. Selain varietas Ciherang juga varietas Ciliwung (Gonjak dan Passeno), IR-64 (Sumberejo dan Selosari), Membramo (Selosari, Passeno, Sumberkalong), Sintanur (Selosari dan Sumberkalong), Cisantana dan IR-74 (Passeno), Widas dan Cilosari (Karangbaru). Sedangkan varietas jagung adalah C7, Pioneer (Selosari) varietas tembakau (Sumberkalong) adalah Kasturi, Samboris dan Berli. Sedangkan varietas bawang putih di Karangbaru kurang dikenal namanya.

Tabel 4. Varietas-Varietas Tanaman yang Digunakan Petani di Desa Beragroekosistem Sawah dan Lahan Kering, Patanas, 2005.

\begin{tabular}{llll}
\hline \multicolumn{2}{c}{$\begin{array}{c}\text { Agroekosistem/ } \\
\text { Desa }\end{array}$} & Komoditas & \multicolumn{1}{c}{ Nama Varietas } \\
\hline I. & Lahan sawah & & \\
1. & Sumberejo & padi & Ciherang, IR64 \\
2. Sampalan & padi & Ciherang \\
3. Selosari & padi & Ciherang, IR64, Memberamo, Sintanur \\
4. Gonjak & padi & Ciherang, Ciliwung \\
5. Passeno & padi & Ciherang, Ciliwung, Cisantana, Memberamo, IR74 \\
6. & Karangbaru & padi & Ciherang, Widas, Cilosari
\end{tabular}




\begin{tabular}{|c|c|c|c|}
\hline 7. & Sumberkalong & $\begin{array}{l}\text { bawangputih } \\
\text { padi } \\
\text { tembakau }\end{array}$ & $\begin{array}{l}\text { Ciherang, Memberamo, Sintanur } \\
\text { Kasturi, Somboris, Berli }\end{array}$ \\
\hline $\begin{array}{l}\text { II. } \\
1 . \\
2 . \\
3 . \\
4 . \\
5 .\end{array}$ & $\begin{array}{l}\text { Lahan kering } \\
\text { Komering Putih } \\
\text { Mojoagung } \\
\text { Sukaluyu } \\
\text { Karangtengah } \\
\text { Rumbia }\end{array}$ & $\begin{array}{l}\text { ubikayu } \\
\text { ubikayu } \\
\text { kentang } \\
\text { kentang } \\
\text { jagung }\end{array}$ & $\begin{array}{l}\text { Thailand } \\
\text { Adira II, Kuning } \\
\text { Granola } \\
\text { Granola } \\
\text { Bisi-2, C7, Pioneer }\end{array}$ \\
\hline
\end{tabular}

Usahatani bawang putih di Karangbaru dalam beberapa tahun terakhir telah memudar dan telah banyak petani yang meninggalkan usaha ini karena berbagai alasan antara lain gagal panen disebabkan kesulitan menghadapi hama/penyakit, cuaca yang kurang mendukung, permodalan dan sebagainya. Dalam tahun 2004 tanaman bawang putih hanya seluas 30 ha. Keikutsertaan petani dalam usahatani bawang puth di desa ini pada waktu-waktu yang lalu karena adanya bantuan bibit. Pada saat ini umumnya petani lebih berminat pada usahatani tembakau.

Di desa lahan kering di Sukaluyu dan Karangtengah pada umumnya varietas kentang yang ditanam Granola. Varietas ubikayu yang ditanam di Komeringputih adalah Thailand (tidak dapat dikonsumsi karena beracun), sedangkan di Mojoagung adalah Adira II dan Kuning (dapat dimakan). Varietas jagung di Rumbia terdiri dari tiga varietas yaitu Bisi-2, diikuti $\mathrm{C7}$ dan Pioneer.

Secara umum benih/bibit yang ditanam petani di kedua agroekosistem tersebut telah menggunakan varietas unggul. Dalam penggunaan varietas unggul padi sawah, pada awalnya petani membeli benih berlabel dari kios, tapi selanjutnya banyak yang membibitkan sendiri. Demikian pula halnya untuk komoditas-komoditas lainnya.

\section{b. Benih/Bibit dan Pupuk}

Jumlah benih padi yang digunakan untuk pertanaman biasa relatif sudah sesuai dengan anjuran yaitu $25-30 \mathrm{~kg} / \mathrm{ha}$. Sedangkan benih yang diperlukan dalam kegiatan PTT (Pengelolaan Tanaman Terpadu) hanya 8-10 kg (Zaini et.al 2002). Khusus untuk Passeno benih padi sawah yang digunakan petani relatif sangat besar hampir dua kali lipat ( $55 \mathrm{~kg} / \mathrm{ha})$. Hal ini disebabkan sistem tanam yang diterapkan petani di desa ini adalah teknologi tabela (tabur/tebar benih langsung) yang memerlukan benih relatif banyak. Sistem penanaman padi sawah umumnya dilakukan dengan cara tanam pindah.

Tabel 5. Rata-Rata Dosis Benih/bibit dan Pupuk (kg/ha) untuk Berbagai Komoditas di Desa Beragroekosistem Lahan Sawah dan Lahan Kering, Patanas, 2005.

\begin{tabular}{|c|c|c|c|c|c|c|c|c|}
\hline Agroekostem/Desa & Komoditas & $\begin{array}{c}\text { Benih/ } \\
\text { bibit }\end{array}$ & Urea & TSP & $\begin{array}{l}\text { SP. } \\
36\end{array}$ & ZA & $\mathrm{KCl}$ & NPK \\
\hline I. Lahan sawah & Padi & 27 & 349 & 125 & 144 & 343 & 115 & 118 \\
\hline
\end{tabular}




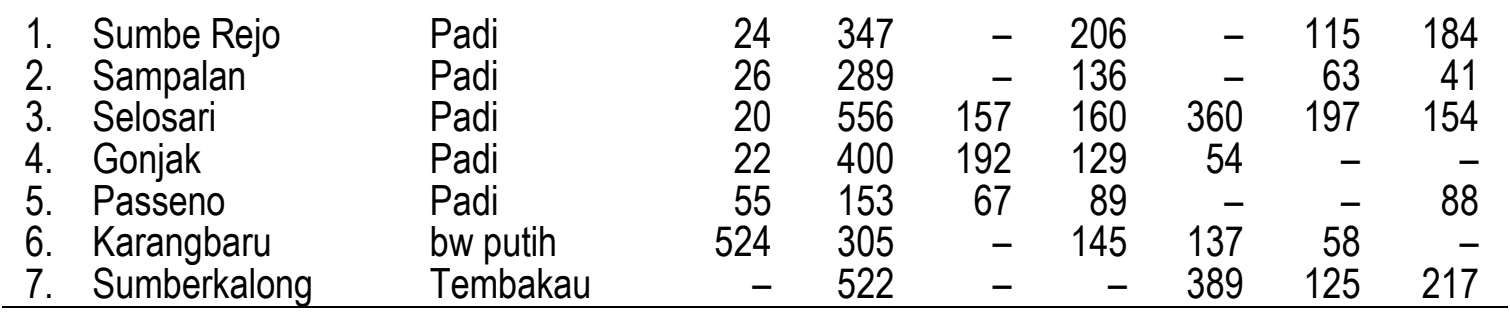

Lanjutan Tabel 5.

\begin{tabular}{|c|c|c|c|c|c|c|c|c|c|}
\hline I. & Lahan kering & & - & - & - & - & - & - & - \\
\hline 1. & Komering Putih & ubi kayu & - & 164 & 100 & 100 & 100 & 77 & 250 \\
\hline 2. & Mojoagung & ubi kayu & - & 424 & 100 & 133 & 100 & 100 & - \\
\hline 3. & Sukaluyu & Kentang & 1650 & 379 & - & 358 & 278 & 211 & 547 \\
\hline 4. & Karangtengah & Kentang & 2100 & 543 & 267 & 257 & 243 & 196 & 274 \\
\hline 5. & Rumbia & Jagung & 12 & 359 & - & 99 & 152 & 200 & - \\
\hline
\end{tabular}

Menurut Tabel 5 terlihat bahwa secara umum dosis pemupukan telah melebihi dosis anjuran terutama Urea. Pengaruh pemberian pupuk Urea yang berlebihan dapat menyebabkan a) biaya produksi meningkat, b) tanaman peka terhadap hama/penyakit, c) tanaman (terutama padi) mudah roboh, d) perkembangan gulma cepat, dan e) terjadinya pencemaran lingkungan oleh nitrat, nitrat dan gas emisi NO2 (Las et al 2002).

\section{c. Penggunaan Pupuk}

Untuk tanaman padi, pupuk yang umum digunakan adalah Urea dan SP-36, disusul TSP (di Sampalan tidak digunakan), KCl dan NPK (Sumberejo, Sampalan dan Selosari). Sedangkan ZA digunakan oleh sebagian petani Selosari dan Gonjak. Penggunaan pupuk $\mathrm{KCl}$ yang merupakan komponen dari pemupukan berimbang masih belum banyak diadopsi petani.

Dilihat dari jenis pupuk yang digunakan petani untuk tanaman padi maka yang telah menggunakan pupuk relatif lengkap adalah petani Sampalan, Selosari, Sumberejo dan Passeno (Tabel 6).

Tabel 6. Persentase Petani Pengguna Berbagai Jenis Pupuk di Desa Padi Sawah, Patanas 2005

\begin{tabular}{lcccccccc}
\hline \multicolumn{1}{c}{ Desa } & Urea & TSP & SP-36 & ZK & KCI & ZA & NPK & Organik \\
\hline Sumberejo & 100 & 4 & 56 & 0 & 20 & 0 & 16 & 8 \\
Sampalan & 100 & 0 & 96 & 0 & 13 & 0 & 21 & 0 \\
Selosari & 100 & 20 & 16 & 0 & 12 & 40 & 40 & 0 \\
Gonjak & 100 & 28 & 60 & 0 & 0 & 4 & 0 & 0 \\
Passeno & 100 & 60 & 16 & 0 & 0 & 0 & 8 & 0 \\
\hline Total & 100 & 23 & 49 & 0 & 9 & 9 & 17 & 2 \\
\hline
\end{tabular}


Untuk tanaman kentang, dilihat dari segi jumlah pupuk yang digunakan maka jenis pupuk buatan yang banyak digunakan adalah SP-36 di Sukaluyu dan Urea di Karangtengah. Terdapat persamaan pada penggunaan pupuk organik dalam jumlah yang sangat besar. Jenis pupuk yang digunakan untuk ubikayu di kedua sentra (Komeringputih dan Mojoagung) relatif sama, yaitu Urea, SP-36 dan $\mathrm{KCl}$. Untuk tanaman jagung di Rumbia pupuk yang digunakan adalah Urea, ZA dan SP-36 serta pupuk organik.

Urutan jenis pupuk yang banyak digunakan untuk semua komoditas di kedua agroekosistem dapat dilihat pada Tabel 7. Menurut Harianto dan Katherina (2005) penggunaan lahan yang berlebihan (overused land) dengan penambahan input yang berlebihan dapat menyebabkan tidak saja berkurangnya produksi tetapi kerusakan permanen dari lahan tersebut seperti hilangnya unsur hara yang diperlukan untuk meningkatkan produksi usahatani. Melihat manfaat usahatani yang begitu besar bagi manusia maka manfaat jangka panjang menjadi prioritas penting bagi usahatani berkelanjutan.

Tabel 7. Urutan Jenis Pupuk yang Digunakan Petani di Desa Beragroekosistem Lahan Sawah dan Lahan Kering Menurut Komoditas, Patanas, 2005.

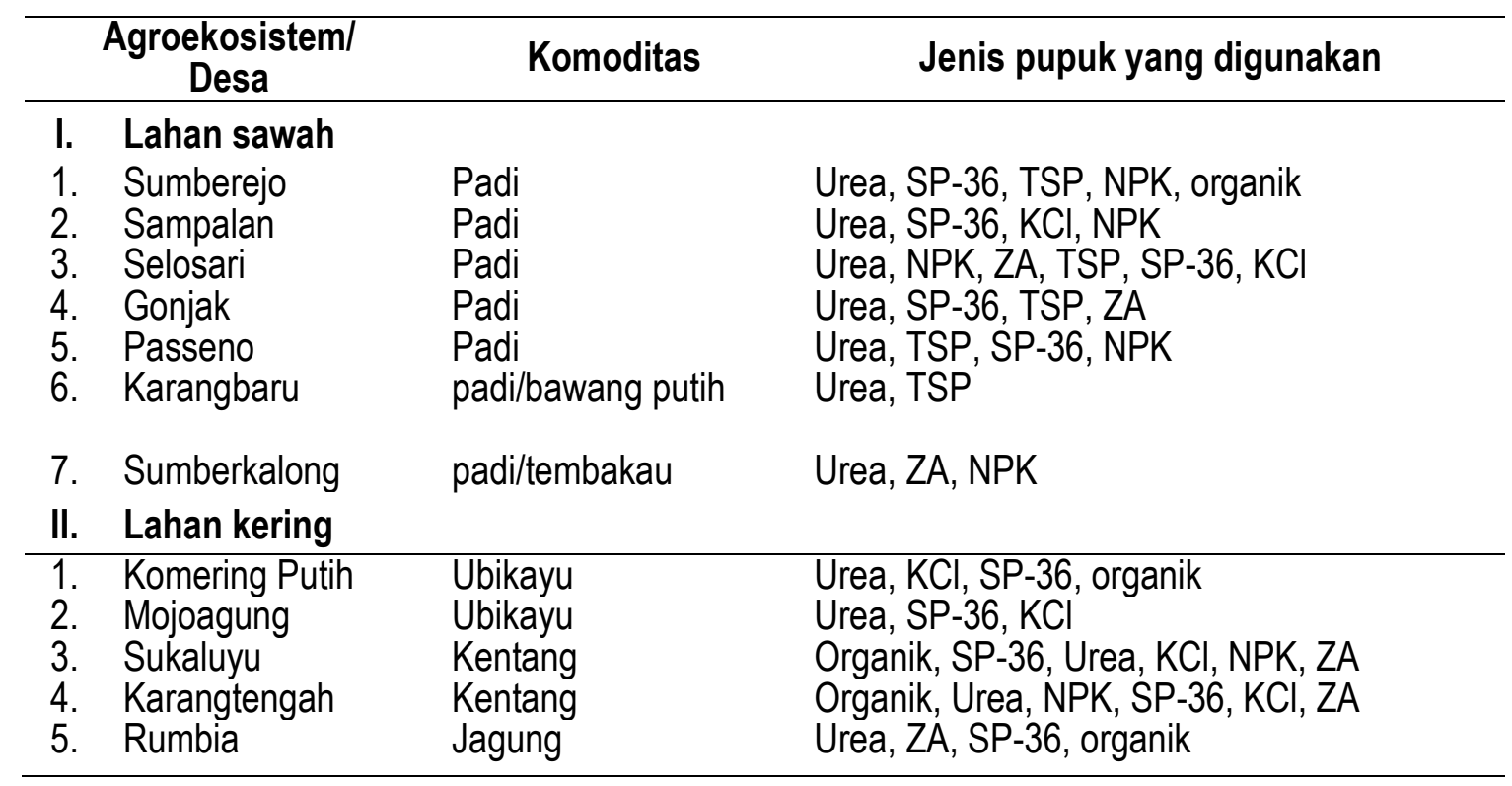

\section{d. Obat-Obatan}

Insektisida untuk memberantas hama serangga pada umumnya telah digunakan petani padi di seluruh desa berbasis sawah. Herbisida (pemberantas gulma) banyak digunakan petani di Passeno dan Sumber Rejo dan sebagian kecil petani di Sampalan. Untuk usahatani kentang (Sukaluyu dan Karang Tengah) penggunaan pestisida (insektisida dan fungisida) sudah 
merupakan suatu keharusan terutama untuk menyelamatkan produksi dari serangan hama dan penyakit yang relatif banyak mengganggu pertumbuhan kentang dan herbisida untuk memberantas gulma, sehingga untuk usahatani kentang jenis obat yang digunakan lebih banyak. Komponen biaya obat-obatan untuk melaksanakan usahatani kentang sangat besar.

Dalam pelaksanaan usahatani ubikayu pada umumnya baik di Komering Putih maupun Mojoagung tidak ada petani yang menggunakan insektisida untuk memberantas hama karena hama pada tanaman ubikayu relatif tidak ada. Tapi dalam hal ini telah banyak petani yang menggunakan herbisida. Demikian juga halnya di sentra produksi jagung (Rumbia) petani lebih mengutamakan penggunaan herbisida, sedangkan insektisida jarang digunakan karena hama jagung relatif tidak ada.

\section{e. Tenaga Kerja}

Penggunaan alat mesin pertanian pada usahatani padi sawah terutama traktor banyak digunakan untuk pengolahan lahan dan thresher (perontok) untuk kegiatan pasca panen. Penggunaan traktor di beberapa desa masih dikombinasi dengan penggunaan ternak kerja. Penggunaan ternak kerja untuk pengolahan lahan masih banyak dimanfaatkan petani di Selosari, Gonjak dan Sumberejo. Penggunaan thresher lebih banyak digunakan oleh petani di Luar Jawa.

Pengolahan lahan di desa lahan kering lebih banyak memanfaatkan tenaga kerja manusia atau tenaga ternak sapi/kuda. Tenaga manusia untuk pengolahan lahan banyak digunakan di Sukaluyu dan Karangtengah, penggunaan traktor tidak memungkinkan karena medannya sulit. Di Karang Tengah alat mesin yang banyak digunakan adalah pompa untuk kegiatan penyiraman, untuk penanaman kentang musim kemarau. Alat juga digunakan untuk menyemprot pemberantasan hama/penyakit. Ternak sapi banyak digunakan untuk pengolahan lahan di Mojoagung dan Komeringputih, sedangkan pengolahan lahan di Rumbia ternak yang lebih dominan digunakan adalah kuda, karena kemampuan kuda lebih besar dari sapi.

\section{Penyebaran Lahan Usaha}

Pengusahaan lahan akan lebih efisien bila lahan berada dalam satu kesatuan areal yang utuh karena lahan yang terpencar apalagi dalam petakan yang sempit dapat mengakibatkan pengelolaan usahatani tidak efisien. Berdasarkan agroekosistem lahan usahatani di desa lahan sawah lebih terpencar dibandingkan dengan desa lahan kering. Telah lama Soehardjo dan Patong (1973) mengemukakan bahwa beberapa kerugian yang timbul karena terpencarnya lahan usahatani ialah: a) petani kehilangan waktu yang produktif untuk mencapai semua lahan yang letaknya terpencar, b) pengawasan terhadap apa yang diusahakan pada masing-masing lahan 
sangat sukar, c) petani tidak leluasa memilih tanaman yang paling menguntungkan, d) banyak lahan produktif untuk pematang, e) pembagian air pengairan sulit diatur, dan f) penggunaan alatalat mekanisasi sulit dilakukan. Dilihat dari status penguasaan maka lahan milik lebih terpencar (terfragmentasi) dibandingkan dengan lahan bukan milik. Jumlah rata-rata persil di kedua agroekosistem berdasarkan kepemilikan dapat dilihat pada Tabel 8.

Tabel 8. Rata-Rata Jumlah Persil (Lahan Dominan) di Desa Beragroekosistem Lahan Sawah dan Lahan Kering, Patanas, 2005

\begin{tabular}{clrrrr}
\hline & Agroekosistem/ & \multicolumn{2}{c}{ Lahan Milik } & \multicolumn{2}{c}{ Lahan Bukan Milik } \\
\cline { 2 - 5 } & \multicolumn{1}{c}{ Desa } & Rata-Rata & Maksimum & Rata-Rata & Maksimum \\
\hline I. & Lahan sawah & 1,81 & 7,00 & 1,28 & 3,0 \\
1. & Sumberejo & 1,68 & 5,00 & 1,10 & 2,0 \\
2. & Sampalan & 1,20 & 2,00 & 1,43 & 2,0 \\
3. & Selosari & 2,67 & 7,00 & 1,00 & 1,00 \\
4. & Gonjak & 1,14 & 3,00 & 1,43 & 2,00 \\
5. & Passeno & 2,43 & 6,00 & 1,41 & 3,00 \\
6. & Karangbaru & 1,53 & 3,00 & 1,15 & 2,00 \\
7. & Sumberkalong & 1,65 & 5,00 & 1,20 & 2,00 \\
\hline II. & Lahan kering & 1,73 & 4,00 & 1,27 & 2,00 \\
1. & Komeringputih & 2,27 & 4,00 & 1,43 & 2,00 \\
2. & Mojoagung & 1,68 & 3,00 & 1,00 & 1,00 \\
3. & Sukaluyu & 1,50 & 3,00 & 1,00 & 1,00 \\
4. & Karangtengah & 1,17 & 2,00 & 1,00 & 1,00 \\
5. & Rumbia & 1,92 & 4,00 & 1,27 & 2,00 \\
\hline
\end{tabular}

\section{Tingkat produktivitas}

Tingkat produktivitas rata-rata lahan sawah untuk setiap sentra produksi menunjukkan bahwa secara umum tingkat produktivitas lahan pada MH lebih tinggi dibandingkan dengan MK kecuali di Passeno karena iklimnya berlawanan dengan iklim di Jawa (Tabel 9). Secara agregat rata-rata produktivitas tersebut lebih tinggi dibandingkan dengan produktivitas padi sawah ratarata tingkat nasional tahun 2003 dan 2004 yang masing-masing mencapai 47,50 ku/ha dan 47,43 ku/ha (BPS 2005).

Tabel 9. Produktivitas Rata-Rata Padi Sawah di Desa Beragroekosistem Sawah, Patanas, 2005

\begin{tabular}{clccc}
\hline \multirow{2}{*}{ No. } & \multicolumn{1}{c}{ Desa } & MH & Produktivitas (ku gkg/ha) \\
\cline { 2 - 4 } & \multicolumn{1}{c}{ MK } & Agregat \\
\hline 1. & Sumberejo & 43,26 & 27,68 & 39,79 \\
2. & Sampalan & 60,56 & 47,58 & 54,07 \\
3. & Selosari & 56,23 & 43,26 & 49,74 \\
4. & Gonjak & 60,56 & 43,26 & 51,91 \\
5. & Passeno & 51,91 & 69,21 & 60,56 \\
6. & Karang Baru*) & 43,26 & 34,60 & 38,93 \\
7. & Sumber Kalong $\left.{ }^{* *}\right)$ & 56,23 & - & - \\
\hline
\end{tabular}




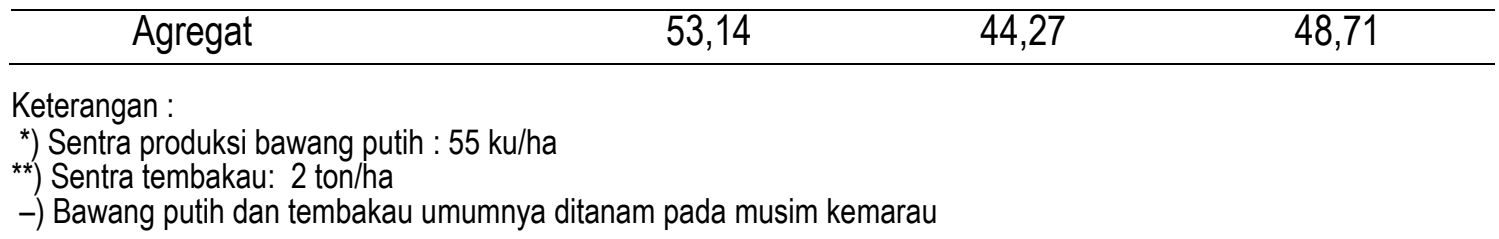

Produksi rata-rata kentang di Sukaluyu sekitar 18 ton/ha, sedangkan di Karang Tengah sebesar 17 ton/ha. Dilihat dari produktivitas rata-rata tersebut relatif tidak berbeda. Secara nasional tingkat produktivitas kentang Jawa Barat lebih tinggi dibandingkan Jawa Tengah. Tingkat produktivitas kentang Indonesia pada tahun 2003 dan 2004 masing-masing adalah 15,3 ton/ha dan 14,2 ton/ha. Namun frekuensi pengusahaan kentang di Karang Tengah lebih tinggi dibandingkan di Sukaluyu. Di Karang Tengah kentang diusahakan sepanjang tahun (3 kali), sedangkan di Sukaluyu umumnya hanya sekali dan paling banyak dua kali.

Produktivitas rata-rata ubikayu di Komering putih relatif lebih tinggi dibandingkan dengan di Mojo Agung. Produktivitas rata-rata ubikayu di Komering Putih 25 ton/ha, sedangkan di Mojo Agung 20 ton/ha. Secara nasional produktivitas ubikayu Provinsi Lampung lebih tinggi dibandingkan Jawa Tengah. Secara nasional produktivitas ubikayu di kedua provinsi tersebut lebih tinggi dibandingkan produktivitas ubikayu nasional yang pada tahun 2003 dan 2004 masingmasing 15 ton/ha dan 16 ton/ha (BPS 2005). Tetapi terdapat kecenderungan harga ubikayu di Mojo Agung lebih tinggi dibandingkan dengan di Komering Putih.

Produktivitas rata-rata jagung pada penanaman $\mathrm{MH}$ di Rumbia lebih tinggi dibandingkan dengan MK. Produktivitas rata-rata jagung MK berkisar 50-70 persen hasil panen $\mathrm{MH}$, hal ini terutama disebabkan penanaman pada MK menghadapi masalah kesulitan air. Produktivitas jagung pada $\mathrm{MH}$ rata-rata $40 \mathrm{ku} / \mathrm{ha}$ pipilan kering. Secara agregat (produktivitas $\mathrm{MH}$ dan MK) produktivtas jagung di daerah ini relatif lebih tinggi dibandingkan produktivitas rata-rata Indonesia yang pada tahun 2003 dan 2004 masing-masing sebesar 32,41 kw/ha dan 33,36 kw/ha.

\section{Permodalan dan Ketersediaan Tenaga Kerja}

Menurut Mubyarto (1983), modal adalah nomor dua pentingnya dalam produksi pertanian dalam arti sumbangannya pada nilai produksi setelah lahan. Modal adalah barang atau uang yang bersama faktor-faktor produksi lahan dan tenaga kerja menghasilkan produksi pertanian.

Salah satu kendala yang dihadapi para petani untuk mengembangkan usahataninya adalah kurang akses ke sumber permodalan (Sudaryanto et al 2000) Pada umumnya petani di kedua agroekosistem untuk melaksanakan usahataninya menggunakan modal sendiri. Sistem 
"yarnen" merupakan alternatif yang dilakukan petani untuk dapat melaksanakan usahataninya. Di desa sawah sistem yarnen tidak terbatas hanya untuk mendapatkan sarana produksi, tetapi juga untuk biaya pengolahan tanah (Passeno). Khusus di Sampalan pada umumnya petani mendapat bantuan modal yang berasal dari KKP (Kredit Ketahanan Pangan). Selain di Passeno sistem yarnen banyak dilakukan petani di Sumber Rejo dan Karang Baru.

Di desa lahan kering sistem yarnen ditemui di Sukaluyu dan Karang Tengah yang keduanya merupakan sentra produksi kentang. Sistem yarnen selain kepada kios saprotan juga dilakukan kepada tengkulak (Sukaluyu).

Pada umumnya di kedua agroekosistem tenaga kerja yang dibutuhkan untuk melaksanakan kegiatan usahatani mudah diperoleh dan tersedia sepanjang tahun. Di desa sawah peranan tenaga kerja keluarga terutama untuk kegiatan pemeliharaan (penyiangan, pemupukan dan penyemprotan) demikian juga halnya di desa lahan kering kecuali di Sukaluyu.

\section{Pemasaran Hasil}

Pemasaran hasil produksi merupakan mata rantai produksi yang memiliki peranan penting karena pada dasarnya pemasaran hasil sama pentingnya dengan proses produksi. Kemampuan produksi yang besar akan berkurang artinya bila tidak dapat dipasarkan karena pada akhirnya imbalan harga yang memadailah yang akan menjadi kunci kegairahan petani dalam berproduksi (Mosher 1973).

Penjualan padi pada umumnya dilakukan setelah gabah hasil panen dari sawah diangkut ke rumah, jadi gabah yang dijual dominan dalam bentuk gabah kering panen (GKP). Ongkos angkut gabah ke rumah yang telah dirontok oleh pemanen menjadi tanggungjawab pemilik, kecuali di Sampalan gabah diangkut ke rumah menjadi tanggungjawab pemanen. Sistem penjualan gabah di Karang Baru umumnya dilakukan dengan cara borongan. Cara borongan ini mirip tebasan, tetapi dalam hal ini hasil panen ditimbang. Pembayaran sesuai dengan kuantitas dan harga dilaksanakan setelah dikurangi upah panen (besarnya 10.000/ku gabah). Dari pengalaman petani menunjukkan pada umumnya harga gabah MK lebih baik dibandingkan dengan harga $\mathrm{MH}$. Harga jual gabah $\mathrm{MH}$ bisa lebih rendah dari harga dasar.

Bawang putih ditanam pada $\mathrm{MH}$, biasanya di panen setelah daunnya kering dan selanjutnya dapat langsung dijual atau disimpan beberapa lama menunggu harga lebih baik, karena harga bawang putih sangat berfluktuasi. 
Penjualan hasil tembakau tergantung cara menjual. Berdasarkan tahapan pemetikan, penjualan hasil dapat 2-4 kali. Hasil pemetikan biasanya dikeringkan baru dijual. Di Sumber Kalong sudah umum petani menjual tembakaunya dengan sistem tebasan satu kali pemanenan.

Hasil produksi kentang umumnya dijual setelah mengalami sortasi (memerlukan waktu 2-4 hari). Kualitas kentang terdiri dari 4 kelas, yaitu $A B, A B C, T L$ dan TR. Kualitas yang umum dijual adalah $A B C$, kualitas lainnya digunakan untuk konsumsi atau kebutuhan benih.

Cara penjualan ubi kayu di Komering Putih dan Mojoagung relatif sama, yaitu hasil panen dari ladang langsung dijual ke pabrik dengan cara borongan oleh tenaga upahan mulai dari cabut sampai diterima pabrik yang memberlakukan ketentuan rafraksi. Dengan adanya rafraksi harga ubikayu yang diterima petani menjadi lebih rendah dibandingkan dengan harga pabrik (harga lebih rendah 30 persen), misalnya harga yang diterima petani Rp. 200,-/kg padahal petani seharusnya menerima Rp. 260,-/kg.

Hasil panen jagung di Rumbia dijual dalam bentuk pipilan kering 2-4 minggu setelah panen. Waktu ini digunakan untuk mengangin-anginkan tongkol sebelum dipipil. Pemipilan dapat menggunakan tresher dengan cara menyewa atau secara manual. Namun umumnya dilaksanakan dengan cara manual yang dapat dilakukan siang atau malam secara santai sambil menonton TV atau mendengarkan radio. Harga jagung hasil panen MK lebih baik dibandingkan dengan $\mathrm{MH}$, tetapi volume produksinya lebih kecil (50-70 persen) hasil panen $\mathrm{MH}$.

Harga komoditas selain padi dan jagung (kentang, ubikayu, bawang putih dan tembakau) lebih berfluktuasi. Hal ini diduga karena sampai saat ini untuk komoditas-komoditas tersebut belum ada penetapan harga dari pemerintah. Berfluktuasinya harga di tingkat petani tersebut karena posisi tawar (bargaining position) petani sangat lemah. Harga produk di tingkat petani merosot, meskipun harga di tingkat konsumen cukup baik (Adnyana 2005).

\section{Kelembagaan Pengusahaan Lahan}

Dalam usahatani lahan merupakan faktor produksi penting. Lahan yang diusahakan dapat berupa miliknya sendiri atau milik orang lain. Petani yang mengusahakan lahan miliknya sendiri disebut petani pemilik dan petani yang mengusahakan lahan milik orang lain disebut petani penggarap. Petani penggarap dapat digolongkan berdasarkan cara mendapat lahan milik orang lain untuk dikerjakan sehingga ada petani penyewa, petani penyakap (diperoleh dengan perjanjian bagi hasil) dan terdapat juga penggadai. Di pedesaan secara umum terdapat empat macam bentuk penguasaan lahan yaitu garapan milik, sakap, sewa dan gadai (Sumaryanto et al 1999). Di luar keempat macam bentuk tersebut, juga dijumpai kasus-kasus 
lain berupa pinjam, numpang dan lain-lain yang bersifat lokal dan frekuensi penerapannya sedikit.

Pada umumnya di kedua agroekosistem lahan milik digarap sendiri oleh pemiliknya. Di desa berbasis sawah, sistem sakap lebih dominan dibandingkan sistem sewa, sedangkan di desa lahan kering sistem sakap telah disamai oleh sistem sewa. Di desa lahan kering relatif jarang dijumpai sistem gadai kecuali di Rumbia. Sistem gadai di desa sawah dijumpai di Sampalan, Gonjak dan Sumberejo. Transaksi gadai di NTB terutama untuk membiayai keberangkatan TKI ke luar negeri atau naik haji. Berdasarkan informasi transaksi gadai di Sampalan cenderung meningkat namun pemilik lahan semakin tidak mampu menebus kembali. Transaksi gadai di desa lahan kering tidak dijumpai meskipun berdasarkan informasi dari Pamong Desa dan tokoh masyarakat transaksi ini masih ada.

Disamping sebagai pemilik penggarap, petani di desa sawah maupun lahan kering juga merangkap sebagai penyakap, penyewa atau penggadai. Namun petani dengan status penggarap (penyakap dan penyewa) pada umumnya tidak melakukan kontrak/perjanjian lagi dengan sistem pengusahaan lahan lainnya, artinya mereka tetap sebagai penyakap atau penyewa murni.

Secara agregat transaksi penggarapan sistem bagi hasil/sakap lebih populer daripada sistem sewa. Hal ini ditunjukkan oleh persentase petani dengan status penyakap (penyakap murni atau pemilik) lebih besar daripada persentase petani dengan status penyewa (penyewa murni atau pemilik penyewa). Adanya status rangkap dari pemilik penggarap menunjukkan bahwa penyakap atau penyewa tidak selalu berasal dari golongan yang tidak berlahan (tuna kisma). Ini artinya para pemilik lahan juga masuk dalam pasar sakap, sewa dan juga gadai. Keadaan ini sesuai dengan temuan sebelumnya yang diungkapkan oleh Sumaryanto dan Pasaribu (1996), Susilowati (1996), Saleh dan Zakaria (1996), Sugiarto (1996) dan Susilowati et.al (2000) yang masing-masing dilakukan di Lampung, Jawa Tengah, Sulawesi Selatan, NTB dan Jawa Barat. Namun khusus di daerah sentra produksi kentang (Sukaluyu dan Karang Tengah) tidak dijumpai sistem sakap, tetapi di daerah ini sistem sewa lebih menonjol. Desa-desa ini merupakan daerah yang mengusahakan komoditas yang bernilai ekonomi tinggi (relatif terhadap padi dan palawija). Tingginya risiko berusahatani kentang diduga sebagai salah satu faktor berkembangnya sistem sewa, karena pemilik lahan lebih menyukai sistem sewa yang pasti daripada sistem sakap yang masih berisiko. Sistem sakap lebih berkembang di desa sawah dibandingkan di desa lahan kering. Di desa lahan kering pemilik penggarap murni lebih tinggi dibanding petani di desa sawah (Tabel 10). Beberapa 
faktor yang diduga menyebabkan hal tersebut antara lain ketimpangan distribusi pemilikan lahan, luas rata-rata pemilikan lahan dan tingkat keterbukaan masing-masing desa terhadap kesempatan non pertanian dan tingkat upah. Distribusi pemilikan/penggarapan lahan di desa sawah lebih timpang dibandingkan dengan di desa lahan kering, sedangkan rata-rata luas garapan di desa lahan kering lebih luas dibandingkan dengan desa-desa sawah (Nurmanaf et al 2004).

Tabel 10. Persentase Petani Menurut Status Penguasaan Lahan di Desa Beragroekosistem Sawah dan Lahan Kering, Patanas, 2005

\begin{tabular}{|c|c|c|c|c|c|c|c|c|c|c|c|c|}
\hline & $\begin{array}{l}\text { Agroekostem/ } \\
\text { Desa }\end{array}$ & A & B & C & D & $A B$ & AC & $A D$ & BC & BD & $C D$ & Total \\
\hline I. & Lahan sawah & 64 & 22 & 1 & 3 & 6 & 3 & 1 & 0 & 0 & 0 & 100 \\
\hline 1. & Sumberejo & 60 & 20 & 0 & 0 & 12 & 4 & 4 & 0 & 0 & 0 & 100 \\
\hline 2. & Sampalan & 68 & 16 & 0 & 8 & 0 & 0 & 4 & 0 & 0 & 0 & 100 \\
\hline 3. & Selosari & 88 & 0 & 4 & 0 & 0 & 8 & 0 & 0 & 0 & 0 & 100 \\
\hline 4. & Gonjak & 32 & 4 & 0 & 16 & 8 & 0 & 0 & 0 & 0 & 0 & 100 \\
\hline 5. & Passeno & 44 & 36 & 0 & 0 & 20 & 0 & 0 & 0 & 0 & 0 & 100 \\
\hline 6. & Karangbaru & 48 & 40 & 4 & 0 & 0 & 8 & 0 & 0 & 0 & 0 & 100 \\
\hline 7. & Sumberkalong & 68 & 24 & 0 & 0 & 0 & 0 & 0 & 0 & 0 & 0 & 100 \\
\hline I. & Lahan kering & 84 & 4 & 3 & 0 & 6 & 2,5 & 1 & 0 & 0 & 0 & 100 \\
\hline 1. & Komeringputih & 76 & 8 & 0 & 0 & 12 & 0 & 0 & 0 & 0 & 0 & 100 \\
\hline 2. & Mojoagung & 76 & 10 & 10 & 0 & 0 & 5 & 0 & 0 & 0 & 0 & 100 \\
\hline 3. & Sukaluyu & 84 & 0 & 4 & 0 & 4 & 8 & 0 & 0 & 0 & 0 & 100 \\
\hline 4. & Karangtengah & 96 & 0 & 4 & 0 & 0 & 0 & 0 & 0 & 0 & 0 & 100 \\
\hline \multirow[t]{2}{*}{5.} & Rumbia & 88 & 4 & 0 & 0 & 4 & 0 & 0,8 & 0 & 0 & 0 & 100 \\
\hline & Rata-rata & 74 & 13 & 2 & 1,5 & 6 & 2,75 & 1 & 0 & 0 & 0 & 100 \\
\hline
\end{tabular}

Keterangan :

$A=$ pemilik; $B=$ penyakap; $C=$ penyewa; $D=$ penggadai

Sistem penguasaan lahan yang melibatkan dua pihak pemilik dan penggarap dalam proses transaksi secara ekonomi memiliki posisi/kekuatan yang berbeda. Dalam sistem sakap pertimbangan kemanusiaan lebih menonjol, yaitu adanya hubungan antara pemilik dan penggarap, sedangkan dalam sistem sewa/gadai pertimbangan ekonomi sangat menentukan terjadinya transaksi tersebut. Berdasarkan hal tersebut maka dapat dikemukakan bahwa salah satu penyebab mengapa sistem bagi hasil (sakap) lebih populer dan cenderung lebih berkembang karena faktor risiko usahatani lebih rendah (risiko usaha dibagi antara pemilik dan penggarap), sedangkan pada sistem sewa, petani menyewakan lahan karena pemilik lahan didesak kebutuhan untuk modal usahatani atau kebutuhan keluarga lainnya. Dengan adanya kebutuhan yang 
mendesak pemilik lahan berada pada posisi yang lemah. Di lain pihak pemilik modal/uang cenderung memilih sistem gadai dibanding sewa karena pada waktu tertentu modal/uang akan kembali. Dalam sistem sewa modal tidak akan kembali dan akan lebih rugi lagi apabila terjadi kegagalan panen. Dibandingkan dengan sewa, sakap masih lebih tradisional. Sewa merupakan cara pengalihan hak garap yang lebih lugas dan mengarah pada transaksi dengan pembayaran tunai. Oleh karena itu tingkat sewa sangat dipengaruhi mekanisme pasar yang mencerminkan tingkat produktivitas lahan tersebut. Menurut Gunawan dan Pasandaran (1989) perubahan tingkat sewa sebagai respons terhadap pasar dan produktivitas lahan diperkirakan lebih cepat berkembang dibandingkan dengan perubahan sakap/bagi hasil, terutama di desa-desa sentra produksi yang mengusahakan komoditas bernilai ekonomi tinggi (misalnya sayuran) dan dengan tingkat kesuburan lahan yang baik. Pada sakap, faktor-faktor lain yang melatarbelakangi cukup kompleks, karena bagi hasil ditentukan oleh tradisi setempat, tidak semata-mata oleh faktor ekonomi. Bentuk perubahan penguasaan lahan dengan sistem sakap, sewa dan gadai hanya bersifat sementara, sedangkan perubahan penguasaan lahan melalui proses pewarisan/hibah dan jual beli bersifat tetap.

Pada dasarnya hubungan pemilik penyakap lebih ditentukan oleh hubungan famili atau saling percaya, sedangkan sewa-menyewa tergantung kepada kemampuan seseorang untuk membayar sewa. Dalam kontrak perjanjian, penyewa mempunyai kepastian waktu sedangkan bagi penyakap tidak ada kepastian, sehingga petani penyewa harus bersiap-siap supaya pada akhir jangka waktu sewa sudah tersedia lagi dana yang cukup untuk melakukan lagi penyewaan lahan sebagai syarat kelangsungan usahanya, sedangkan bagi penyakap kecenderungan mempersiapkan untuk kelangsungan usahataninya relatif tidak ada. Maka unsur penting yang terdapat pada petani penyewa adalah rangsangan kuat untuk memperoleh keuntungan yang lebih besar dari usahanya. Perbedaan sistem sewa dan sakap dapat dilihat dari Tabel 11.

Tabel 11.Pengambilan Keputusan dan Sifat Hubungan Antara Sistem Sewa dan Sakap

\begin{tabular}{lll}
\hline \multicolumn{1}{c}{ Uraian } & \multicolumn{1}{c}{ Sewa } & \multicolumn{1}{c}{ Sakap } \\
\hline $\begin{array}{l}\text { 1. Pengambilan keputusan } \\
\text { - memilih lahan garapan }\end{array}$ & Penyewa & $\begin{array}{l}\text { Pemilik lahan } \\
\text { - jenis tanaman }\end{array}$ \\
2. Penggunaan/penyediaan & Penyewa & Pemilik lahan \\
- modal & Penyewa & Pemilik lahan/penyakap \\
- saprotan & Penyewa & Pemilik lahan/penyakap \\
- tenaga kerja & Penyewa & Penyakap \\
3. Cara berproduksi & Penyewa & Pemilik lahan/penyakap \\
4. Menanggung resiko & Penyewa & Pemilik lahan/penyakap \\
\hline
\end{tabular}




\begin{tabular}{lll}
\hline 5. Pemanfaatan produksi & Penyewa & Pemilik lahan/penyakap \\
6. Membayar pajak & Pemilik lahan & Pemilik lahan \\
7. Sifat hubungan & - ekonomis & - non ekonomi \\
& - lugas & - kekeluargaan \\
& - komersial & - kemanusiaan \\
& - bebas/siapa saja & - famili/akrab \\
\hline
\end{tabular}

Tabel tersebut mengungkapkan bahwa pengusahaan/ pengelolaan lahan usahatani yang dilakukan penyewa relatif sama seperti yang dilakukan oleh pemilik penggarap, sedangkan pengambilan keputusan oleh penyakap sebagian besar dipengaruhi pemilik lahan. Sifat hubungan antara penyewa-pemilik bersifat komersial dan langsung.

Sistem penyakapan yang merupakan sistem kelembagaan dominan di pedesaan dapat berbeda antar desa. Di desa sawah sistem penyakapan yang dikenal adalah maro dan mertelu, sedangkan khusus di Karang Baru sistem penyakapan disebut "ngeraksa". Dalam sistem ngeraksa ini semua biaya ditanggung pemilik sehingga penggarap lebih berperan sebagai pengawas. Pada waktu panen si pengawas mendapat bagian sebesar 10 persen dari hasil panen (berupa uang atau natura). Selain sistem ngeraksa, maka di Sampalan masih berjalan sistem "ceblokan" yaitu yang mengerjakan kegiatan penyiangan berhak untuk memanen hasilnya dengan mendapat bawon sebesar $1 / 6$ bagian dari hasil. Sedangkan di Sumberkalong dikenal sistem "betonan", dimana tenaga yang mengolah lahan berhak memanen dengan mendapat bawon 1/5 bagian (20 persen). Bila ada orang yang ingin ikut panen kepada penceblok/pembeton maka upah bawonnya setengah bagian dari jatah penceblok/pembeton tersebut. Dalam kasus ini menunjukkan bahwa tenaga kerja kontrak ikut menanggung bersama risiko kegagalan panen. Keadaan ini sangat menguntungkan pemilik lahan, di lain pihak keadaan ini mengindikasikan bahwa tenaga kerja/buruh tani di pedesaan berlimpah. Selain itu juga menunjukkan posisi pemilik lahan lebih kuat dibandingkan buruh tani, sehingga proporsi yang menjadi bagian tenaga kerja/buruh tani ditentukan oleh pemilik lahan yang biasanya mendominasi tradisi setempat. Upah buruh panen akan semakin rendah lagi, bila buruh panen ikut panen pada penceblok/pembeton, karena upahnya hanya setengahnya (hasil panen dibagi dua dengan penceblok/pembeton). Dalam kasus ngeraksa, kasus panen ini tidak ada.

Dari ketiga sistem tersebut secara umum dapat dikemukakan bahwa pada dasarnya semua itu merupakan bentuk kontrak kerja/borongan kerja yang dibayar kemudian dalam bentuk natura (hasil panen) dalam proporsi tertentu tergantung kebiasaan setempat. Kondisi ini mengindidikasikan bahwa posisi tawar (bargaining position) tenaga kerja/buruh tani lemah. 
Secara umum perbedaan antara sistem maro dan mertelu adalah sebagai berikut: 1). Sistem maro, hasil panen dibagi dua sama besar antara pemilik lahan dan penggarap. Biaya sarana produksi, iuran-iuran, biaya panen dibagi dua, sedangkan seluruh biaya tenaga kerja ditanggung penggarap, pajak dibayar pemilik. 2). Sistem mertelu, hasil panen dibagi untuk pemilik satu bagian dan penggarap dua bagian ( $1: 2$ ). Semua biaya ditanggung oleh penggarap, kecuali pajak dibayar pemilik. Secara umum sistem maro lebih dominan dibandingkan sistem mertelu.

Khusus di Passeno dalam sistem maro berlaku ketentuan sebagai berikut : biaya pupuk dan pengairan dibagi dua, sedangkan benih, obat-obatan dan biaya pengolahan lahan ditanggung penggarap. Pembayaran pajak tergantung kesepakatan dan hasil panen dibagi dua. Sedangkan sistem mertelu berlaku seperti di desa lain.

Meskipun dari sampel tidak ada penyakapan, namun dari hasil wawancara kelompok yang melibatkan pamong desa dan tokoh masyarakat di desa berbasis lahan kering khususnya di Karang Tengah sistem penyakapan terdiri dari 3 macam, yaitu maro, seperempat (mrapat) dan seperlima. Dalam sistem maro, pemilik lahan menanggung biaya pengolahan lahan dan pupuk (organik dan buatan), sedangkan penggarap menanggung biaya pemeliharaan, bibit dan obat. Biaya tanam, biaya pengairan/ penyiraman ditanggung bersama. Hasil panen dibagi dua. Sistem seperempat, hasil panen dibagi dengan komposisi satu banding tiga, satu bagian untuk pemilik dan 3 bagian untuk penggarap. Dalam sistem ini biaya tenaga kerja, bibit, pupuk dan obat ditanggung penggarap, sedangkan pemilik menanggung biaya pengolahan lahan dan pajak. Sedangkan dalam sistem seperlima (1:4), hasil panen dibagi dengan komposisi satu banding empat, satu bagian untuk pemilik dan 4 bagian untuk penggarap. Dalam hal ini pemilik lahan hanya menanggung biaya pajak.

\section{KESIMPULAN DAN IMPLIKASI KEBIJAKAN}

1. IP di desa sawah maupun lahan kering telah mencapai 200 bahkan 300 , kecuali untuk Sumberejo pencapaian IP 200 menghadapi masalah karena adanya giliran pembinaan irigasi, demikian pula halnya dengan di lahan kering yang mengusahakan ubikayu hanya ditanam satu kali dalam setahun.

2. Benih/bibit yang digunakan petani umumnya varietas unggul. Penggunaan semua jenis pupuk cenderung melebihi ketentuan, terutama penggunaan pupuk Urea. Untuk tanaman ubi kayu dan jagung tidak ada perlakuan insektisida, tetapi yang menonjol penggunaan herbisida. Penggunaan jenis pupuk dan obat-obatan di sentra produksi kentang paling banyak jenisnya. Di kedua agroekosistem lahan milik lebih terpencar dibandingkan dengan lahan bukan milik. 
3. Produktivitas padi dan jagung pada $\mathrm{MH}$ lebih tinggi dibandingkan dengan produktivitas $\mathrm{MK}$ kecuali di Passeno terjadi kebalikannya. Produktivitas kentang terbaik diperoleh pada penanaman MK1.

4. Dalam melaksanakan usahataninya pada umumnya petani mengandalkan modal sendiri. Permodalan merupakan masalah yang dihadapi sehingga kebanyakan petani belum dapat melaksanakan sesuai dengan keinginannya. Sistem yarnen merupakan alternatif yang banyak ditempuh. Kelangkaan modal sangat dirasakan oleh petani kentang yang sangat memerlukan biaya yang relatif besar. Tenaga kerja mudah diperoleh sepanjang tahun.

5. Pada umumnya hasil panen dijual di rumah menunggu pembeli. Harga gabah dan jagung MK lebih baik dibandingkan dengan harga $\mathrm{MH}$. Harga gabah $\mathrm{MH}$ dapat berada di bawah harga dasar. Harga komoditas selainm padi dan jagung berfluktuasi.

6. Pada umumnya status petani adalah pemilik penggarap. Secara agregat transaksi penggarapan sistem bagi hasil/sakap lebih populer dibandingkan sistem sewa. Sistem sakap tidak ditemui di sentra produksi kentang. Di daerah ini sistem sewa lebih menonjol, hal ini diduga karena lebih kepada pertimbangan ekonomi daripada kemanusiaan.

7. Dalam pelaksanaan penyakapan, sistem maro lebih menonjol dibandingkan dengan sistem mertelu. Di desa sawah dijumpai kelembagaan lahan di luar sistem tersebut, yaitu "ngeraksa" di Karang baru, "ceblokan" di Sampalan dan "betonan" di Selosari. Selain sistem maro dan mertelu juga ada sistem seperempat dan seperlima.

8. Penerapan teknologi budidaya yang dilaksanakan petani secara umum belum sesuai dengan anjuran, di satu pihak terdapat penggunaan input yang melebihi anjuran (seperti penggunaan pupuk $\mathrm{N}$ ) di lain pihak masih banyak dijumpai penggunaan pupuk di bawah anjuran (penggunaan pupuk P2O5, K2O dan pupuk organik), sehingga secara umum petani belum melaksanakan pemupukan berimbang. Dari keadaan ini dapat diindikasikan bahwa petani masih memerlukan bimbingan dan bantuan dari pihak terkait terutama yang berhubungan dengan pelayanan penyuluhan dan bantuan permodalan atau kredit. Pelayanan penyuluhan untuk memperbaiki manajemen usaha dan kredit membantu permodalan usaha pada saat ini mengalami stagnan dan sulit dijangkau petani karena harus ada agunan dan prosedur administrasi yang masih menyulitkan petani. Sehingga dengan berfungsinya lembagalembaga terkait tersebut petani dapat melaksanakan usahatani yang lebih baik dan berkelanjutan.

\section{DAFTAR PUSTAKA}


[BPS]. 2005. Statistik Indonesia 2004. Jakarta.

Gunawan, M dan E. Pasandaran. 1989. Alokasi Masukan dalam Sistem Sakap. Dalam: Prosiding Patanas Evaluasi Kelembagaan Pedesaan di Tengah Perkembangan Teknologi. Puslit Agro Ekonomi. Hal 19-31.

Harianto dan Katharina. 2005. Pertanian dan Lingkungan. Pelayaran dan Usahatani Lahan Kering Dataran Tinggi. Dalam Krisnamurthi (Ed). Menumbuhkan Ide dan Pemikiran Pembangunan Sistem dan Usaha Agribisnis. 60 Tahun Bungaran Saragih. Pusat Studi Pembangunan Pertanian dan Pedesaan. LPPM IPB. Hal 252-264.

Hermanto. 1984. Pola Pemilikan dan Pengusahaan Lahan di Jawa Timur. Forum Penelitian Agro Ekonomi (FAE), Vol. 3 No. 2 Desember 1984. Puslit Agro Ekonomi. Bogor. Hal. 9 -18.

Husodo SY. 2003. Membangun Kemandirian di Bidang Pangan. Suatu Kebutuhan Bagi Indonesia. Artikel Tahun II No. 6 HKTI Jakarta 15 hal.

llahauw J, Suwondo dan Widjajanto. 1985. Penguasaan Tanah Serta Implikasinya Terhadap Keketatan Budidaya dalam Mubyarto (Ed). Peluang Kerja dan Berusaha di Pedesaan. BPFE. Yogyakarta. Hal 209-295.

Mosher AT. 1973. Menggerakkan dan Membangun Pertanian. Syarat-syarat Pokok Pembangunan Pertanian. Cetakan ke 4. CV. Yasaguna. Jakarta.

Mubyarto. 1983. Pengantar Ekonomi Pertanian. LP3ES Jakarta.

Nurmanaf AR, Djulin A, Surpriadi, Sugiarto, Supadi, Agustin, Sinuraya dan Budhi. 2004. Analisis Struktur Sosial Ekonomi Masyarakat Pedesaan. Laporan Penelitian Puslitbang Sosek Pertanian Bogor.

Saleh C dan Zakaria AK. 1996. Dinamika Distribusi Penguasaan Lahan Pertanian di Pedesaan Sulawesi Selatan. Puslit Sosek Pertanian Bogor.

Sudaryanto T, Rusastra dan Jamal E. 2000. Kebijaksanaan Strategis Pembangunan Pertanian di Pedesaan dalam Mendukung Otonomi Daerah. Prosiding Perspektif Pembangunan Pertanian Pedesaan dalam Era Otonomi Daerah. Puslit Sosek Pertanian, Hal 1-12.

Sugiarto. 1996. Distribusi dan Kelembagaan Penguasaan Lahan di Provinsi Nusa Tenggara Barat. Puslit Sosek Pertanian.

Sumaryanto dan SM. Pasaribu. 1996. Struktur Penguasaan Tanah di Pedesaan Lampung. Puslit Sosek Pertanian Bogor.

Susilowati SH. 1996. Struktur dan Distribusi Lahan Pertanian (Studi Pedesaan Jawa Tengah). Puslit Sosek Pertanian Bogor.

Susilowati SH, Sugiarto, Zakaria AK, Sudana W, Supriadi H, Supadi, lqbal M, Suryani E, Syukur M, dan Soentoro. 2000. Studi Dinamika Ekonomi Pedesaan (Patanas). Puslit Sosek Pertanian Bogor.

Zaini Z, Las I, Suwarno, Haryanto B, Soentoro dan Ananto E.E. 2002. Pedoman Umum Kegiatan Percontohan Peningkatan Produktivitas Padi Terpadu. Badan Litbang Pertanian. 